QIJIS: Qudus International Journal of Islamic Studies

Volume 5, Issue 1, February 2017

\title{
ISLAMIC VALUES IN THE TRADITION OF SAMIN COMMUNITY IN EAST JAVA
}

\author{
Renny Oktafia and Imron Mawardi \\ Airlangga University, Surabaya, East Java, Indonesia \\ renny.oktafia@umsida.ac.id
}

\begin{abstract}
Samin culture is one of sub-cultures in East Java. Samin community in East Java settles in Bojonegoro district. In popular culture, Samin has a lot of wisdom values that are in accordance with Islamic culture values. The wisdom values in Samin community culture need to be analyzed and preserved in order to improve the people livelihood. It creates safe, peaceful, just and prosperous civilization and reaches the nation's development objectives. In traditional Islam, it can be used as a guidance in forming the syar'i law. Terms used in Islam for local traditions referred as 'urf. U'rf can be used as syar'i legal guidelines for 'urf is not contrary with the Qur'an and Hadith. There is synergy between local culture and Islamic culture. The community life activities are in accordance with the teachings of religion but the local culture is preserved for its continuity.
\end{abstract}

Keywords: culture of Samin, 'urf, islamic values

\section{A. Introduction}

Since the economic crisis in 1997, economic condition in Indonesia today still continues to slump. The current economic system is still referring to the capitalist economic system which 
is proved unable to provide solutions to the problems of the economy in this country. It is necessary to think and do other approaches that are quite capable in addressing this continuing economic crisis. Cultural approach can be used as an alternative as well as solutions in facing this economic crisis problems. This is due to the culture of self-contained wisdom values which we will discuss further. Culture is an entity that continuously merges with the existence of a community life.

Based on the above ideas, the development of the economy of East Java also should pay attention to its cultural potency. According to Sutarto (2004), in East Java, there are ten areas of culture, namely the region of Javanese culture Mataraman, Java Panaragan, Arek, Samin (Sedulur Sikep), Tengger, Osing (Using), Pandalungan, Madura Island, Madura Bawean, and Madura Kangean. Each sub-culture has different characteristics. The cultural community has advantages and disadvantages which can be used as a strategic force in improving the quality of life, so they can be used to create prosperity for local communities around.

The advantages and disadvantages of each sub-culture are present in cultural wisdom values. They are in behavior in the form of words and deeds of each cultural community. One of sub-cultures in East Java mentions that the values of wisdom can be explored, developed and disseminated to support regional development. The values of wisdom are contained in Samin tribal traditions. Samin tribal communities in East Java live in the north of East Java which is precisely located in Bojonegoro district.

Bojonegoro Regency is one of regencies in the province of East Java. The district borders other districts in East Java. On the north, it borders Tuban district. On the east, it borders Lamongan district. in the south, it borders counties and districts of Madiun Nganjuk, while the west borders Blora district. In Bojonegoro district, there is also the Watershed (DAS) Bengawan Solo which runs just on the north of Bojonegoro so that this region becomes a fertile agricultural region. In addition, Bojonegoro district in the 
south is an area of limestone mountains which stretches along the southern part of that district.

In terms of economic growth record in Bojonegoro, inflation that occurred was said to be quite low at $2.91 \%$ in 2015 . The rate of inflation in Bojonegoro district was lower than the rate of inflation in East Java regional level 3.08\%, and the rate of inflation that occurred at the national level was 3.35\% in the same year. By looking at such conditions, it is still necessary to have big efforts so that it will be more creative and innovative, in order to push down the rate of inflation that occurred in Bojonegoro (www.bojonegorokab.go.id, 2015).

To make breakthroughs in these efforts, there are some approaches in policy making which can be used as an attempt to curb inflation and to strengthen the community's economy of Bojonegoro. One approach that can be glimpsed as a cornerstone of the policy makers is a cultural approach. Lots of values of local wisdom are contained, have been practiced and become a tradition among the community. In conducting the activities of the economy, we can learn. apply and develop economic activities.

Bojonegoro is as a territory which is inhabited by Samin tribes. Then, according to the description above, it can explore the values of Samin tribe wisdom to be used as an approach in policy making to realize the construction progress for Bojonegoro. Cultural aspects contained in Samin tribe is an integral part in the development process. The values of wisdom contained in Samin community culture is an asset which can create a quality development, whether it is physical or non-physical development for local communities.

Samin tribe doctrine itself contains a lot of Islamic values which can counteract with the effects of modernization that do not fit well according to Islam and cultural values Samin tribe. Modernization is often referred as the development of the current development. In fact, construction of which refers to the modern 
system like the capitalist system do not carry the development towards better, but it can decrease the development.

According to Jatman (2000: 22-25), the nature of life in Java community has ideal life characters. Those are wise, honest, introspective, heartfelt, mindful, satria, respect, harmonious, and friendly. The lively character is also a living character owned by Samin community. Those characters let us to look at the two characters of life. Those are «honest» which means not lying, upright, and do not cheat, and the «mindful» which means always remember God Almighty (www.kbbi.web.id, 2016 ). So when we apply economic development activities, the result will be different. They must be honest in sharing profits because they always remember if they are not honest, there is Allah who will know what they do.

Thus, the values of Samin tribe local wisdom which is reflected in the nature of life are in accordance with the teachings of Islam. One of them is mentioned in the Quran surah An-Nahl 105, as follows:

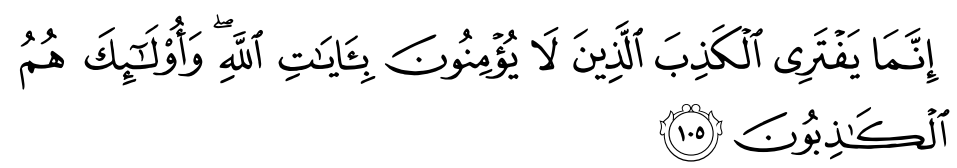

"They only invent falsehood who do not believe in the verses of Allah, and it is those who are the liars."

In Islam, if there are behaviors and actions that are considered good, as well as the local community, they will become a habit. Then, it can be used as the applicable law and prevailing in the region. Whereas in Islam, a habit that can create creativity and build cultural values which acts as a tradition in general and performed by a group is referred to as $>$ urf (Zainuddin, 2015). If we can explore the values of Samin community cultural wisdom which contain the values of Islam in accordance with the existing texts, then if it is used as a local community development approach, it will obtain a formula for policy development with tremendous force. 


\section{B. Discussion}

According to LIPI (Suhanah, 2011), the term used to mention Samin is derived from the founders of Samin community. His name is Surosentiko Samin. He spread the message that all human beings have the same degree. Samin assume that the degree of aristocracy or the position of the Dutch people who colonized our country is same with the others. This Samin teachings upholds human rights, by not treating people based on high or low social status. In addition, the term Samin can also be derived from the Javanese term, namely sami-sami amin which means agree with each other in achieving prosperity for together.

So even according to Abdul Wahib in (Suhanah, 2011), something unique that Samin tribe has is their ideology, where their movement is a unique phenomenon. Samin community is known as people who oppose the rules imposed by the government of the Netherlands which was related to the obligation to pay taxes and submit their harvest to the Dutch government. This community is very opposed to arbitrary decision committed by the Dutch who were forcibly seize Samin community property in the form of land to expand the planting of teak forests. Another uniqueness is also reflected in the attitude that Samin people have innocence, but the their innocence has the ingenuity, so it can outwit the Dutch colonizers.

According to Kluckhohn in Munawaroh (2015: 68), it is said that the definition of cultural values are all things that bring meaning to life, which is summed up in a concept that resides in the minds of most people. Cultural value orientation lies in all forms that is considered valuable to people>s lives and become a value system that is always growing with the development of society. With the formation of this cultural value system, then the network among community members there will be more closely even raised the bond between them, so that they will always try to keep it up any time. In the cultural value, there are 5 orientations: first, everything that is related to the essence of life; secondly, 
with regard to the nature of work and man>s work; third, with regard to the nature of humanity in space and time; fourth, with regard to the human relationship with the natural surroundings; and fifth, with regard to the nature of man>s relationship with other humans.

Samin tribe initially embraced the Shiva-Buddhist religion; that is a syncretism between Hinduism and Buddhism. Then after Islam came, syncretization happen between Shiva-Buddhist religious teachings with the teachings of Islam. In the social system, Samin tribe has a doctrine embraced by the community that their action must be good, honest and patient. And all of them are covered in Uri Uri Budaya. Doctrine which teaches us to be wise, honest and patient is known as the teaching and called Angger-Angger which consists of three things: first, Angger-Angger Pratikel which means the laws relating to behavior; second, Angger-Angger Pengucap which means law with respect to the rules of speaking; and the third, Angger-Angger Lakonono which means the law about everything with regard to things that need to be implemented (Widiana, 2015).

Meanwhile, according to Munawaroh (2015: 70-87), the values of Samin community wisdom are also reflected in the way Samin tribe live. Samin society $>$ s view about the meaning of life consists of: the meaning of the Samin community creator, Samin community meaning to the natural environment, and the meaning of Samin community of fellow human beings. In the concept of making sense of the creator, the Samin community assume that all people who live on this earth must have goals so that everything done by humans is a reflection of life goals that want to be achieved, everything that is good or bad will have the impacts and the human beings will feel them depend on their actions, then they must be good to everyone, to plants and animals. The point is all creatures in this universe.

For the concept of Samin tribal in the elucidation of the natural environment, it can be said that Samin tribe in life can not be separated from the natural environment, so intertwined 
reciprocal relationship that humans need is nature for their survival. And, the natural environment was to keep its continuity so it is necessary to be wise man so they can reach the purposes of human life. Therefore, nature is very important to Samin people>s lives and they always learn to adapt to nature. Related to the nature, Samin community has something fair. Because their livelihood is as farmers, Samin always behave in harmony with nature both with plants and animals.

Form of their closeness to the nature is shown by Samin community. One of them is the attitude of Samin community in looking at the water, they assumed that water is the source of life that it cannot be separated from human life, animals and plants, so they should be wise in using the water in order to maintain continuity. In conserving water, Samin community use water according to their needs and other relatives who also need water for their daily needs as well as for irrigation of agricultural land. Another form of closeness that looks natural on Samin community is about prohibition for Samin community in cutting down trees that grow around water sources, if they need to cut down trees, they should plant a replacement trees.

Meanwhile, with regard to the concept of the meaning of fellow human beings which is owned by Samin community, some of the rules are contained in the teachings of Samin community life. So they can use them as the way to interact in the community every day. According to Samin community, they do not do some things like srei, dengki, dahwen, nyolong mbedog which means that they should not be the one whose jealousy. They should not be people who like to admit other people's goods and should not be someone who likes stealing the property of others.

In speaking, there are also some rules which should be followed. Some of them are: waton among, which means forbidden talk nonsense; yen omong nganggo waton which means when talking, we must talk the truth. Then there are also the laws of behavior among the doctrine of life. One of them is pengucap saka lima bundhelane lan pengucap saka sanga bundhelane ana pitu 
which means that to the other people, we must always be careful that the attitude that we do will not hurt others. In addition, there is also a related doctrine of life in law enforcement. The term is lakonana sabar, trokal sabare dieling-eling, trokale dilakoni which means that Samin people should be patient in life. On the other hand, they also must work diligently; and the term wong urip ana alam donyo kuwi kudu duweni lima tujuan: demen, becik, rukun, seger, lan waras which means that in life, there are five objectives that should be owned by Samin community, namely happiness, kindness, harmony, freshness and health.

The word Samin is from the words 'sami-sami amin'. It means that they should keep the togetherness and unity in real life. This principle creates an atmosphere with terms duwekku yo duwekmu; duwekmu yo duweku which means 'mine is yours and yours is mine'. According to Samin community, they never distinguish people by seing high or low position, rank or wealth. They are then led to the term sak padha padha that has meaning 'all problems can be solved through mutual cooperation as long as being pillars, guyub (do together) and help each other. To foster a sense of togetherness, Samin community has a custom called Sadranan which is usually held every Senin Pon (Monday-'Pon' is the name of pasaran in Java) after the implementation of the harvest. In Sadranan, citizens visit each house and then served with traditional food which is made from raw material yields.

The description above is so clear that the values of cultural wisdom are contained in the cultural values of Samin community. It can be seen that there are many great cultural values that have benefit for humans and the natural environment. For that reason, we should learn together about all forms of Samin community cultural values. After we study the cultural values well, hopefully we can preserve the values of Samin community cultural wisdom in order to make the values survive and continue to grow in warding the negative impacts. 
Islam teaches that man must move forward in this life, then what is done today must be better than yesterday, as written in the Qur'an Surah Hashr 18 as follows:

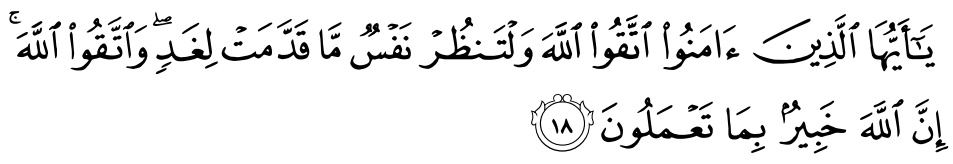

"O you who have believed, fear Allah. And let every soul look to what it has put forth for tomorrow - and fear Allah . Indeed, Allah is Acquainted with what you do".

In making changes as mentioned above, it can be formed by the values contained in these communities. It will produce the norms of life as a way of life in a society to shape their lives according to the values which have been agreed.

Value of life formed from behavioral changes that had been abandoned in the past is a form of shifting values, and the values contained in the pattern of social life is called as customs, culture, and tradition. Thus, it can be concluded that the culture is a manifestation of the activity of the life values in society with the results generated from these activities (Setiyawan, 2012). According to Qamaruddin in Setiyawan (2012), the accumulation of activity that has been ongoing and done repeatedly will be something embedded in the hearts of every individual so the such condition is then considered as custom forming process.

Islam itself looks indigenous people or culture as one of the elements that can be used as one tool in determining the laws of Personality. They should conduct filter selectively and proportionately so the culture will not be contradicted with the texts that exist, so it can be legalized and used as the Islamic Shari'ah. Based on these explanations, in establishing Islamic law, Islam can use the custom. According to Zuhaili in Zainuddin (2015), the laws of Personality may be shaped by human habits that form the habit of a general nature and habits of particular importance, and can be used as a reference in judging something when proposition in the texts is not found. 
Ifrosin (2007: 6) says that the custom made by a community that produces creative and imaginative cultural values is called as 'Urf in Islam. According to Al-Qaradawi in Abdullah (2008), 'urf is also allowed in Islam because the Qur'an and Hadith have two forms of proposition. First, the argument qat'i mentions that proposition is broke and clear; secondly, the argument that is zanni which contains general principles which are usually associated with muamalah activity. According to Al-Qaradawi, the arguments of a general nature are intended to give flexibility to the Mujtahids to draft a law in accordance with the times, but still must comply with Islamic principles. In addition, the condition of the reality of commercial activities very quickly changes and requires the ulama role in generating ijtihad as a source of law in trade.

Aripin (2016) defines 'urf etymologically as something that contains the values of goodness and accepted by common sense as well as an activity that is done continuously. While according to the terminology, 'urf is defined as any activity in a society in the form of words and deeds understood by a community. Abdul Karim Zaidan divides 'urf based on terms of its scope into two kinds, namely:

1. General indigenous or known as al-urfal $<A m$, which means all forms of prevailing majority custom at a time across the country.

2. Specific indigenous or known as al-urf al-Khas, which means that the indigenous are only applied on a certain society.

According to Ghani (2011), custom or habit is a consensus on any activity carried out by people and obtained through action by practicing regularly. Islam also uses habits as a models form in determining the law, such as when the habits of the inhabitants of Medina in the transaction mudaraba is then used by Islam as one of the rules in conducting commerce in the fields of trade, agriculture and livestock. Another form of agreement in the which the activity becomes a habit is the case of knocking the door in 
visiting someone; it indicates that the guests who come should ask permission to enter.

Fanani (2014) says that Islamic law regulates all aspects of human life, while the problems faced by the community continues to grow. And, law in Islam contained in the Qur>an and the Hadith is not entirely clear set for problems faced by humans, so that Muslim jurists or indigenous culture can be used as an option in dealing with human problems when the practical rules not found in the Qur>an and Hadith. The main purpose of cultural or customary law legalized is in order to achieve welfare and avoid the negative things. There are several key principles in maslahah mursalah. Those maslahah are:

1. Maslahah should be general; all matters are related to public interest.

2. Maslahah should be absolutely essential, that is really intended for the benefit of mankind.

3. Maslahah achieved must not be violated by nash ie the Qur'an and Hadith.

Qadi 'Abd al-Wahhab al-Maliki in Miharja (2011) says that 'urf is recognized as one of the guidelines in resolving the problems faced by the people in a community, but 'urf must meet several requirements as follows:

1. 'urf used is a habit that has been done by most people and has lasted continuously for long periods of time.

2. 'urf has no prior issues to be determined as the law case of its solution.

3. 'urf does not conflict with anything that has been expressed clearly.

4. 'urf does not conflict with existing texts, namely the Qur>an and hadith.

According to Hadi Sjechul Permono in Fanani (2014), there are connections among the customary rules of sharia jurisprudence. 
1. Indigenous existed before Islam, which was later adopted and legitimized by Shari'a.

2. The custom is not legitimized by law in the texts, but to be part of the implementation of the syar'i law, such as the determination of the menstrual period.

3. Indigenous is nothing in the syar'i law and does not become a reference in implementation of syar'i law. This custom is divided into two: first, a custom which is still within the limits of syar'i law permissibility; second, the customary general nature and is contrary to the texts.

The local culture that develops in an area made up the activities of local community, which aims to safeguard the survival of the community. Local culture contains so much wisdom values which can be used to realize maslahah for local communities. It is a strength of social capital that need to be preserved, even need to be applied in daily life. Indonesia is a country with Muslim majority so that the values of Islam must be considered in maintaining cultural heritage. In connection with the values of Islam as a religious doctrine, then the local culture should be in synergy with the Islamic culture. The values of local wisdom should also reflect the cultural values of Islam. At the end, the synergy of local culture and Islamic culture will play an important role in shaping a new culture through the fusion of religious values with the order of local cultural values.

Likewise, when lifting the culture of the community Samin, the values of Islam will be found in the values of Samin tribe cultural wisdom. In Munawaroh, et al. (2015: 39-43), there are several Samin cultural wisdom values which are highly relevant to the values of Islam among other things.

\section{Samin community has a culture that is based on principles of kinship and togetherness}

The principle of kinship and togetherness owned by Samin culture is demonstrated in the activities of mutual cooperation, undertaken with mutual aid in any form of trouble or all the 
problems of life, whether related to individual issues and social problems. Forms of mutual assistance activities undertaken, among other things: activities to build the house, move house building, manage agricultural land, when there are people who have a celebration, and so on. Spirit to help each other owned by Samin community is known as sambatan which means giving help.

The cultural values of mutual cooperation in Samin community are forms of helping each other among local communities. Samin cultural values contained in this splice culture also present in the cultural values of Islam which is known as ta>awun which means helping, but helping in goodness and piety. It is as contained in the Quran surah Al-Maidah (2) as follows:

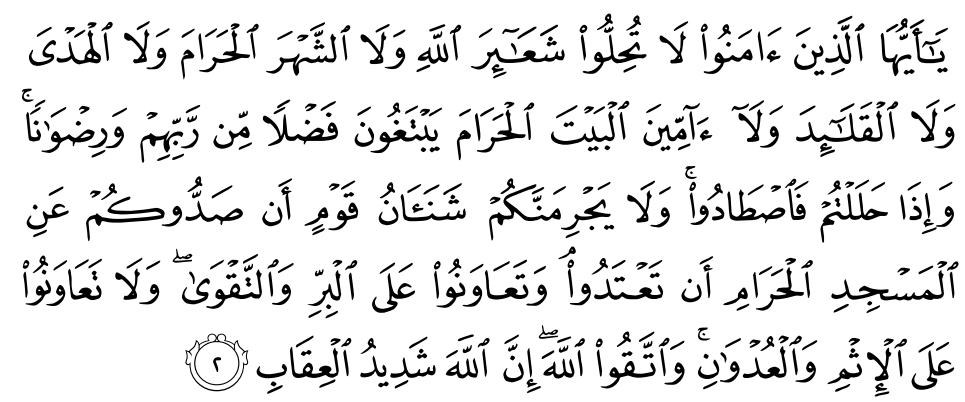

"O you who have believed, do not violate the rites of Allah or [the sanctity of] the sacred month or [neglect the marking of] the sacrificial animals and garlanding [them] or [violate the safety of] those coming to the Sacred House seeking bounty from their Lord and [His] approval. But when you come out of ihram, then [you may] hunt. And do not let the hatred of a people for having obstructed you from al-Masjid al-Haram lead you to transgress. And cooperate in righteousness and piety, but do not cooperate in sin and aggression. And fear Allah ; indeed, Allah is severe in penalty".

Social human beings have become interdependent naturally among one another. Therefore, Islam is aware of human nature, then Islam teaches mutual help between fellow in all the difficulties encountered by humans. Providing assistance should not always be material, but also provide assistance in the form of labor, knowledge, advice, and so on. 


\section{Samin community also has cultural values of kinship, which is called sedulur}

Sedulur is an effort in maintaining and preserving family relationships, a way to place family members when visiting each other despite the distance where he lives very far away. Cultural values sedulur owned by Samin community is also present in the cultural values of Islam, namely the relationship. In Islam, the relationship is a form of obedience to Allah because Allah orders the human beings to connect relationship, as mentioned in the Qur'an Surat ar-Ra'd (21) as follows:

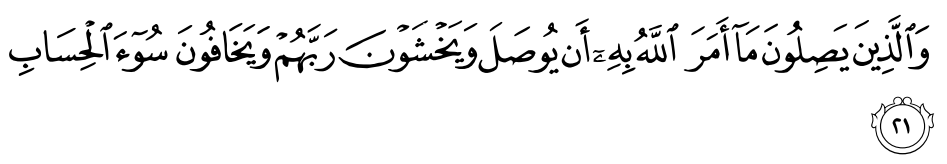

"And those who join that which Allah has ordered to be joined and fear their Lord and are afraid of the evil of [their] account".

In addition, to the cultural values of society also appears on the philosophy Samin community in the sense of life. Munawaroh, et al (2015: 67-87) mention that there are three forms of the meaning of life, namely:

\section{a. Meaning of the Creator}

Samin society assume that every human being has a purpose in life, where the purpose of life of each man depends upon how the man himself to interpret his life. When a man has to understand his purpose in life, it will be easier for him to make sense of his life. In Islam, the purpose of life is to worship Allah, that everything done by humans must be intended for worship. It has been mentioned in the Qur'an surah Adh-Dzaariyaat (56) as follows:

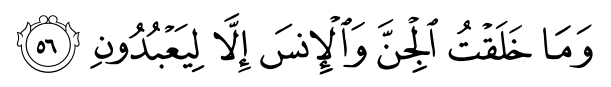

"And I did not create the jinn and mankind except to worship $M e^{\prime \prime}$. 


\section{b. Defining the natural environment}

For Samin people, natural environment and human life are two things that can not be separated because there is a mutual need between both of them. This is because Samin people's livelihood is as farmers so that nature conservation is very important for Samin people. In Islam, there is no doctrine that forbids people to make mischief on earth, as mentioned in the Quran surah Al-Araf (56) as follows:

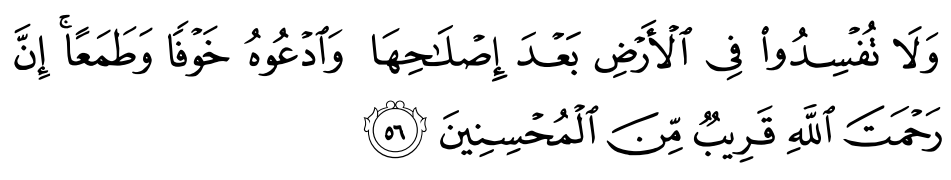

"And cause not corruption upon the earth after its reformation. And invoke Him in fear and aspiration. Indeed, the mercy of Allah is near to the doers of good".

\section{c. Meaning of fellow human beings.}

In Samin community life, related to teaching about the meaning of fellow human beings, there is a doctrine that regulates social relations. The teachings set all communication, behavior and implementation should be done by Samin community. This doctrine is still maintained until now. Samin teachings in the tribal communities are in accordance with the values of Islam that command people to always speak and act well, as explained in the Quran surah Al-Baqarah (263) as follows:

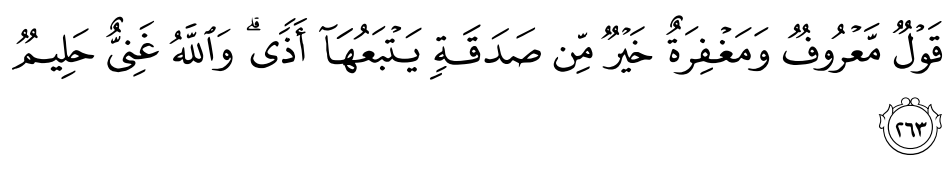

"Kind speech and forgiveness are better than charity followed by injury. And Allah is Free of need and Forbearing."

\section{Conclusion}

Based on the description above, it can be seen that the cultural values of Samin society will teach people about moral values which are used as a guide in performing daily life. Samin culture moral values are also in accordance with the values of 
Islamic culture. Samin community cultural values need to be guarded and preserved so that later, they can be used as a rule of syar>i law to organize the order of a society. If the order of a society can be run well, it will realize the civilization which is secure, peaceful and prosperous. The creation of a civilization that is safe, peaceful and prosperous will be able to make Indonesia becomes a strong, great and respected nation in the world. 


\section{REFERENCES}

Abdullah, A. S. 2008. 'Urf dan Justifikasinya dalam Analisis Hukum Fiqh Al-Mu'amalat. Shariah Journal, Vol. 16, No. 2.

Aripin, M. 2016. Eksistensi Urf dalam Kompilasi Hukum Islam. Jurnal Al-Maqasid, Vol. 2 No. 1.

Fanani, A. 2014. Akar, Posisi, dan Aplikasi Adat dalam Hukum. Jurnal Ijtihad, Vol. 14 No. 2.

Ghani, H. A. 2011. 'Urf -o-Ādah (Custom and Usage) as a Source of Islamic law. American International Journal of Contemporary Research, Vol. 1, No. 2.

Ifrosin. 2007. Fiqh Adat (Tradisi Masyarakat dalam Pandangan Fiqh). Jawa Tengah: Mukjizat.

Jatman, D. 2000. Psikologi Jawa. Yogyakarta: Yayasan Bentang Budaya.

Miharja, J. 2011. Kaidah-Kaidah Al-'Urf Dalam Bidang Muamalah. Jurnal El-Hikam, Vol. IV, No. 1.

Munawaroh, d. 2015. Etnografi Masyarakat Samin Di Bojonegoro (Potret Masyarakat Samin dalam Memaknai Hidup). Yogyakarta: Balai Pelestarian Nilai Budaya.

Setiyawan, A. 2012. Budaya Lokal dalam Perspektif Agama. Jurnal ESENSIA, Vol. XIII, No. 2.

Suhanah. 2011. Dinamika Perkembangan Sistem Kepercayaan Samin di Kabupaten Blora. Jurnal Harmoni, Vol. X, No. 3.

Sutarto, A. 2004. Pendekatan Kebudayaan dalam Pembangunan Provinsi Jawa Timur. Jember: Kompyawisda.

Widiana, N. 2015. Pergumulan Islam dengan Budaya Lokal (Studi Kasus Masyarakat Samin di Dusun Jepang Bojonegoro). Jurnal Teologia, Vol. 26, No. 2.

Zainuddin, F. 2015. Konsep Islam tentang Adat (Telaah Adat Dan Urf Sebagai Sumber Hukum Islam). Jurnal Lisan Al-Hal, Vol. 7, No. 2.

www.bojonegorokab.go.id. 2015.

www.kbbi.web.id. 2016. 
Renny Oktafia and Imron Mawardi

Halaman ini tidak sengaja untuk dikosongkan. 